\title{
Maize Disease Resistance
}

\author{
Peter J. Balint-Kurti and Gurmukh S. Johal
}

\begin{abstract}
This chapter presents a selective view of maize disease resistance to fungal diseases, highlighting some aspects of the subject that are currently of significant interest or that we feel have been under-investigated. These include:
\end{abstract}

- The significant historical contributions to disease resistance genetics resulting from research in maize.

- The current state of knowledge of the genetics of resistance to significant diseases in maize.

- Systemic acquired resistance and induced systemic resistance in maize.

- The prospects for the future, particularly for transgenically-derived disease resistance and for the elucidation of quantitative disease resistance.

- The suitability of maize as a system for disease resistance studies.

\section{Introduction}

Worldwide losses in maize due to disease (not including insects or viruses) were estimated to be about 9\% in 2001-3 (Oerke, 2005). This varied significantly by region with estimates of $4 \%$ in northern Europe and 14\% in West Africa and South Asia (http://www.cabicompendium.org/cpc/economic.asp). Losses have tended to be effectively controlled in high-intensity agricultural systems where it has been economical to invest in resistant germplasm and (in some cases) pesticide applications. However, in areas like Southeast Asia, hot, humid conditions have favored disease development while economic constraints prevent the deployment of effective protective measures.

This chapter, rather than being a comprehensive overview of maize disease resistance, highlights some aspects of the subject that are currently of significant interest or that we feel have been under-investigated. We outline some major contributions to disease resistance genetics that have come out of studies in maize and discuss maize as a model system for disease resistance studies. We discuss primarily resistance to fungal diseases; resistance to insects and viral diseases are dealt with in Chaps. 11 and 12. 


\section{Types of Disease Resistance}

Genetic resistance in plants is often divided into two major classes; Qualitative, or major-gene, resistance, is based on single major-effect resistance genes (R genes) and generally provides race-specific, high-level resistance. Quantitative resistance typically has a multi-genic basis and generally provides non-race-specific intermediate levels of resistance. Genomic regions (or loci) responsible for quantitative effects are known as quantitative trait loci (QTL). Qualtitative resistance, often associated with a rapid cell death called a hypersensitive response (HR) around the point of pathogen ingress, is generally quickly overcome when deployed in the field, though there are exceptions (e.g., Steffenson, 1992). Quantitative resistance tends to be more durable (Parlevliet, 2002). Qualitative resistance is generally effective against biotrophic pathogens (pathogens that derive their nutrition from living host cells), while quantitative resistance is more often associated with resistance to necrotrophic pathogens (pathogens that derive nutrition from dead cells). The mechanisms of quantitative resistance have not been well characterized, but are likely to be variable depending on the specific interaction.

While qualitative resistance is extensively used in the other major grass crops, wheat and rice, only a few major resistance genes, such as the $H t$ genes for resistance to northern leaf blight (Welz and Geiger, 2000) and the $R p$ genes for resistance to common rust (Ramakrishna et al., 2002), have been used in maize breeding. The vast majority of genetic resistance used by maize breeders is quantitative. It is interesting to speculate why this contrast exists. The major factor might be that maize is substantially more genetically diverse than wheat or rice, probably because it alone is an outcrossing species (Buckler et al., 2001). Maize breeders therefore have more diversity available to them within adapted germplasm than their wheat or rice colleagues and consequently are better able to bring together multiple small-effect QTL to achieve effective levels of quantitative resistance. While diverse germplasm is available in wheat, it is often available only from exotic, unadapted sources. In order to maintain agronomic performance, the breeder must minimize the amount of exotic germplasm that is introduced into adapted lines. Therefore, in wheat, single genes of large effect have been much more attractive to breeders. Another factor might be that there simply are fewer commercially important biotrophic pathogens of maize than there are of wheat. It is not clear why this might be, but one can speculate that it is because effective quantitative resistance to these pathogens is available and widely utilized.

\section{Seminal Disease Resistance Genetic Studies in Maize}

As is made clear in this book, maize has been an important model species for many aspects of plant genetics. Disease resistance is no exception. Some key discoveries in the area of disease resistance genetics and resistance gene function that have been made in maize are listed below. 


\subsection{The First Cloning of a Susceptibility Gene to Pathogens}

Maize carrying Texas cytoplasm for male sterility (cms-T) was widely used for hybrid seed production in the 1950s and 1960s. A new race (race T) of the southern corn leaf blight pathogen Cochliobolus heterostrophus emerged in 1969 that was very pathogenic on cms-T maize, causing disease epidemics in 1970 and 1971 (Ullstrup, 1972). It was found that race T produced a family of linear long chain polyketides, collectively called the T-toxin (Pring and Lonsdale, 1989) which binds specifically to URF13, a peptide of $13 \mathrm{kDa}$ that resides in the inner membrane of mitochondria as an oligomer and acts as a ligand-gated channel (Levings, 1990; Levings and Siedow, 1992). Binding of T-toxin to URF13 transforms this channel into a large pore, causing the membrane to become leaky and lose function, somehow leading to cell death, and enhanced colonization of the maize tissue by the pathogen. The T-urf13 gene, which apparently arose by chance in the mitochondrial genome of cms-T maize (Wise et al., 1999) encodes URF13.

URF13 was also exploited by Phyllosticta maydis (Mycosphaerella zea-maydis), previously unknown to cause disease in the United States. (Pring and Lonsdale, 1989). Like C. heterostrophus, M. zea-maydis produces a polyketide of the T-toxin family (PM-toxin) that functions as a specific determinant of virulence/disease of this pathogen on cms-T maize (Wise et al., 1999). So susceptibility to disease in both cases was due to specific interaction of a fungal metabolite with the product of a unique susceptibility gene in the host, and it was averted by simply avoiding the use of cms-T germplasm containing this gene.

In addition to uncovering the first plant gene for disease susceptibility, studies on this disease had additional implications. First, it is still the classic example of the perils of monoculture (Wise et al., 1999), reminding us to that whenever novel germplasm, derived either through traditional or biotechnological means, is widely grown, it can expose the crop to unpredictable risks. It also provided the first example of the involvement of mitochondria in plant disease and the first clear indication of the importance of mitochondrial integrity in cell death control in eukaryotes, an area of biology that exploded in the 1990s.

Although URF13 is also responsible for the male sterile phenotype of cms-T cytoplasm, the mechanistic basis for this remains unclear. A number of nuclear genes, called fertility restorers (Rf), have been identified that suppress the male sterile phenotype of cms-T (Wise et al., 1999). These Rfs, however, failed to restore resistance to pathogens. This is intriguing because some of these Rf factors lower the level of URF13 in mitochondria (Wise et al., 1999).

\subsection{The First Cloning and Characterization of a Disease Resistance Gene}

The Hml gene (Ullstrup, 1941, 1944) confers specific resistance against a leaf blight and ear mold disease of corn, caused by $C$. carbonum race 1 (CCR1). The exceptional virulence of race 1 on susceptible $h m l$ maize is due to production of a 
host specific toxin, HC-toxin, a cyclic tetrapeptide (Ciuffetti et al., 1983; Kawai et al., 1983). Hml was cloned by transposon tagging and was found to be an NADPHdependent HC-toxin reductase, which reduces a key carbonyl group on HC-toxin, thereby inactivating it (Johal and Briggs, 1992; Meeley et al., 1992). The case of HC-toxin offers an interesting contrast to that of T-toxin. For HC-toxin, plant resistance is an active function, requiring the production by the plant of an enzyme to detoxify a fungal pathogenicity factor. Contrastingly, in the case of T-toxin, plant susceptibility is an active function, requiring production by the plant of a toxin binding protein.

\subsection{The Genesis of a Plant Disease and a Grass-Lineage-Specific Disease Resistance Gene}

Studies with $\mathrm{Hm} 1$ and $\mathrm{Hm} 2$ (a duplicate gene at an unlinked locus) have shown that resistance to CCR1 conferred by these genes is almost ubiquitously present in maize germplasm, (Nelson and Ullstrup, 1964; Zhang et al., 2002). Characterization of both $\mathrm{Hm} \mathrm{I}$ and $\mathrm{Hm} 2$ in susceptible maize inbreds revealed that the disruption of both of these disease resistance genes was required for the susceptibility of maize to CCR1 (Multani et al., 1998). All other cereals contain orthologs of $\mathrm{Hml}$ as well as the HCTR activity responsible for the resistance function of this gene and have been considered non-hosts for CCR1 (Meeley and Walton, 1993; Multani et al., 1998). This suggested an ancient origin and recruitment of the Hml disease resistance trait in the grass lineage. Barley leaves in which expression of the $\mathrm{Hml}$ homologs is down-regulated by virus-induced gene silencing become susceptible to infection by $C$. carbonum race 1 , but only if the pathogen is able to produce HC-toxin (Johal et al., unpublished). Phylogenetic analysis has shown that $\mathrm{Hml}$ evolved early and exclusively in grasses, presumably in response to HC-toxinmediated virulence of $C$. carbonum race 1 . These studies provide a rare glimpse into an ancient host-pathogen struggle that occurred at the origin of the grasses. They also have implications for the survival and evolution of grasses; were it not for the $\mathrm{Hml}$ gene, grass evolution might have proceeded quite differently.

\subsection{First Indications of the Complex Nature and Function of $R$ Genes}

Together with the flax/flax rust system, genetic studies of the maize/maize common rust system, specifically at the $R p l$ locus, have elucidated a number of general genetic and mechanistic features of the $\mathrm{R}$ genes:

(1) Studies conducted on the Rpl locus established that it likely had a compound structure, containing tandemly duplicated genes of different specificities or paralogs (Hu and Hulbert, 1994; Richter et al., 1995; Sudupak et al., 1993). 
This structure was thought to be a general feature of $\mathrm{R}$ gene loci which contributed to the genesis and death of R genes (Hulbert et al., 2001) and their complex and unstable nature. The instability of the $R p l$ locus was thought to stem largely from two mechanisms; unequal crossing over at the locus and gene conversion (Hulbert, 1997). These hypotheses were largely confirmed with the eventual cloning of the Rpl locus and other $\mathrm{R}$ gene loci in the 1990s.

(2) It was first shown in maize, again at the $R p l$ locus, that recombination within $\mathrm{R}$ gene loci can lead not only to new $R$ gene specificities but also to aberrant $R$ genes which malfunction and trigger the hypersensitive response (HR) spontaneously, resulting in so-called disease lesion mimics (Hu et al., 1996). This was also the first indication that an $\mathrm{R}$ gene could have two separate functions: pathogen recognition and the activation of the HR response (Pryor, 1987). Recently we have shown that the disease lesion mimic phenotype conferred by the aberrant $\mathrm{R}$ gene $R p 1-D 21$ is quite variable in genetically divergent backgrounds and have mapped some of the loci responsible for this variation (Johal and Balint-Kurti unpublished), which likely are important in the wild-type $R p l$-mediated defense response.

(3) The maize $R p 1$ gene was the first disease resistance gene ever to be tagged with a transposon (Bennetzen et al., 1988). Although instability at the $R p l$ locus frustrated attempts at cloning, this research did uncover an important aspect of the biology of the HR cell death underlying a resistance response; it manifests in a cell autonomous fashion (Bennetzen et al., 1988).

\section{The Genetic Architecture of Disease Resistance in Maize}

More than 50 major $\mathrm{R}$ genes have been cloned in plants (Martin et al., 2003). With some exceptions (e.g., Johal and Briggs, 1992; Multani et al., 1998; Romer et al., 2007; Xiao et al., 2001), most of these genes are dominant and share certain conserved domains such as a nucleotide binding site (NBS) and a leucine-rich repeat (LRR) region (Martin et al., 2003; McDowell and Simon, 2006). A set of genes known as "R gene analogs" (RGAs) have been defined that, while they have no demonstrated function in disease resistance, share these domains. By analyzing the publicly available genomic sequences, 585 RGAs have been defined in the rice cultivar Nipponbare (Monosi et al., 2004) and 149 in Arabidopsis (Meyers et al., 2003). In maize, 228 RGAs have been identified (Xiao et al., 2007) using partial sequence data derived from several different maize lines. Once the complete genome sequence of the standard maize line B73 is available, a more complete analysis will be possible. In all these species, RGAs were found to be located all over the genome, often clustering with groups of three or more RGAs mapping to the same locus, mirroring the clustering of plant $\mathrm{R}$ genes such as at the Rpl locus described above (Smith et al., 2004). Plant RGAs are both highly divergent and rapidly evolving (Ellis et al., 2000), this fact, together with the high level of genetic diversity found within maize (Buckler et al., 2006), suggests that a huge diversity of RGAs, and therefore a huge array of recognitional specificities, is likely available within maize germplasm. 
In maize, one recessive major gene for resistance has been identified, namely $\mathrm{rhm} 1$ which confers resistance to race O of C. heterostrophus (Chang and Peterson, 1995; Zaitlin et al., 1993). It is not clear whether rhml also confers resistance to race T, but it has been shown that the resistance it confers is associated with relatively few changes in gene expression or protein levels (Simmons et al., 2001) and that it is most effective at the seedling stage. In the adult plant $r h m l$ confers a level of quantitative resistance (Thompson et al., 1987, Balint-Kurti; et al, unpublished). In contrast, Hm2 and $\mathrm{HmlA}$ confer adult plant resistance to $C$. carbonum race (Balint-Kurti et al., 2007) but are not effective at seedling stages (Nelson and Ullstrup, 1964).

Unlike qualitative resistance, little is known about the identity or function of disease resistance QTL in any plant species. Despite the apparent differences noted above between qualitative and quantitative disease resistance, one can make the argument that, in some cases at least, pure qualitative and pure quantitative disease resistance are two ends of the same continuum and that most resistance genes reside somewhere between these two extremes. This is exemplified by the Rcgl gene that confers resistance to anthracnose stalk rot disease of maize. In certain populations $R c g 1$ segregates as a major gene for resistance (Badu-Apraku et al., 1987a), while in others it was identified as a QTL (Jung et al., 1994). Thus, in some cases it becomes a semantic question as to whether a gene is a qualitative $\mathrm{R}$ gene or a large-effect QTL. Interestingly, Rcgl was recently cloned and shown to be an RGA (Broglie et al., 2006; Wolters et al., 2006).

Wisser et al (2006) recently summarized 50 publications reporting the mapping of disease resistance genes in maize. These included 437 QTL and 17 major genes. It was determined that reported disease resistance QTL covered $89 \%$ of the maize genome. This high degree of coverage is partly reflective of the relatively low precision and accuracy of QTL mapping (in some cases the confidence interval of a single QTL covered one third of a chromosome). However, just as with the genomewide distribution of RGAs, it also reflects the large number of different loci involved in identified plant pathogen interactions. Wisser et al. (2006) further showed that the distribution of disease resistance QTL in maize was non-random (i.e., they were clustered to some extent) and that often QTL for resistance to different diseases clustered together, mirroring the clustered distribution of $\mathrm{R}$ genes and RGAs in plants (e.g., Milligan et al., 1998; Monosi et al., 2004).

Other reports suggest that disease resistance QTL and R-genes in fact do share some phenotypic characteristics. These include several reports suggesting that specific disease resistance QTL are race-specific (e.g., Avila et al., 2004; Calenge et al., 2004; Qi et al., 1999; Talukder et al., 2004; Zhu et al., 2003), reports showing that "defeated" R genes sometimes provide a basal level of non-specific, quantitative resistance (Li et al., 1999; Stewart et al., 2003) and that some R genes do not provide complete resistance (Choi et al., 1989; Hammond-Kosack and Jones, 1993; Smith and Hulbert, 2005), and reports showing that disease resistance QTL often co-localize with R gene clusters (Gebhardt and Valkonen, 2001; Wang et al., 1994; Welz and Geiger, 2000; Wisser et al., 2005; Yun et al., 2005).

This implies that RGA's may underlie at least some disease resistance QTL in plants. However most maize disease resistance QTL confer resistance to necrotrophic pathogens and, for the most part, resistance to true necrotrophs relies on mechanisms distinct from the $\mathrm{R}$ gene-mediated mechanisms involved in resistance to biotrophs 
(Glazebrook, 2005). Therefore, for a significant proportion of maize disease resistance QTL it seems unlikely that RGAs will turn out to be the causative genes. Other genes involved in a wide variety of processes, including for example epidermal structure (e.g., Bradley et al., 2003), stomatal opening or phytoalexin synthesis (Zhou et al., 1999) might play a role In rice, several gene families, including mitochondrial transcription termination factors and glutathione S-tranferases were reported to be statistically associated with quantitative resistance (Wisser et al., 2005). Other reports have also implicated glutathione metabolism as an important component of disease resistance (Dean et al., 2005; Levine et al., 1994; Parisy et al., 2007). A proline-rich rice gene of unknown function named Pi2l has recently been identified that confers quantitative resistance to rice blast (Fukuoka, personal communication). The high diversity available within maize, together with the genetic resources available make it a compelling system through which to understand the genetic architecture of disease resistance in plants, particularly with respect to quantitative disease resistance.

\section{The Genetic Bases of Resistance to Specific Maize Diseases}

This section briefly covers the main disease types, focusing on the genetics of resistance and highlighting specific points of interest and diseases that are particularly important for economic or food security reasons. For a more comprehensive review of maize diseases, including nematodes, root rots and striga which are not covered here, it is suggested the reader consult a number of recent reviews (Pratt and Gordon, 2006; Smith and White, 1988; White, 1999).

\subsection{Stalk and Ear Rots}

Stalk and ear rots are the most economically damaging of the corn diseases and occur wherever corn is grown. While the damage caused by ear rots in terms of lost yield is significant, their most problematic aspect is the mycotoxins associated with several of their ear rot fungi. These toxins have been associated with a variety of diseases ranging from nausea to neurological conditions to cancer (Richard and Payne, 2002). Here we will briefly discuss the four major ear rot problems (Fusarium, Aspergillus, Diplodia and Giberella) and the four major stalk rots (anthracnose, Giberrella, Fusarium and Diplodia) affecting maize. A common feature of genetic studies of all these diseases, particularly the ear rots, is the relatively high environmental variation observed. This has significantly hampered both investigations of the genetic architecture underlying these traits and the breeding of lines with reliable resistance to these diseases.

The maize ear represents a unique structure within the plant kingdom, quite different from the teosinte ear from which it evolved by artificial selection $\sim 10,000$ years ago, a relatively recent event in evolutionary terms. (Doebley et al., 1997; Piperno and Flannery, 2001; Reeves, 1950). Plant-pathogen interactions are generally thought to 
coevolve over evolutionary time (Clay and Kover, 1996). It is interesting therefore to speculate as to the how the ear rots of corn originated. The answer likely is in the fact that the causal agents of maize ear rots tend to be relatively unspecialized pathogens. The causal agents of three of the four ear rot diseases detailed here have wide host ranges - Aspergillus flavus infects peanuts and cotton seeds among others, and Fusarium verticillioides and Gibberella zeae infect the seeds of rice, maize, and wheat as well as other grasses (Richard and Payne, 2002). In addition, three of the causal agents, Fusarium verticillioides, Gibberella zeae and Stenocarpella maydis are also the cause of important stalk rots. It seems possible therefore that these generalist pathogens were able to form novel interactions with the maize ear in a relatively rapid fashion in evolutionary terms - coming either from phylogenetically closely related hosts or from other maize structures (Parker and Gilbert, 2004).

As mentioned above, three ear rot/stalk rot pairs - Gibberella, Fusarium and Diplodia ear/stalk rot - share a causal organism. Curiously, few data exist on the potential correlations of reactions to ear rots and stalk rots in different maize lines. One study reported that, among 25 inbred lines of dent maize, Diplodia ear rot resistance was not correlated with Diplodia stalk rot resistance and likewise Giberella ear and stalk rot resistances were not correlated (Hooker, 1956).

\subsubsection{The Genetics of Stalk Rot Resistance}

Nyhus et al (1989) demonstrated that recurrent selection for Diplodia stalk rot resistance led to improvements in anthracnose stalk rot resistance. One study of the inheritance of resistance for anthracnose stalk rot indicated that additive effects were most significant (Carson and Hooker, 1981), while another suggested additive, dominance and epistatic effects were important (Badu-Apraku et al., 1987b). Similarly, additive effects have been reported to be most significant for Diplodia stalk rot resistance (Kappelman and Thompson, 1966). A major gene for Gibberella stalk rot resistance has been reported on chromosome 6 (Yang et al., 2004; Pè et al., 1993) reported at least 4 loci providing moderate levels of resistance to Gibberella stalk rot. Jung et al (1994) reported one major QTL for resistance to anthracnose stalk rot, which explained over $50 \%$ of the variation in an $\mathrm{F}_{2: 3}$ population. As mentioned above this QTL has also been described as the major gene Rcgl (Badu-Apraku et al., 1987a) and encodes an RGA (Broglie et al., 2006; Wolters et al., 2006). Arguably, this discovery represents the first report of the sequence of a gene underlying a plant disease resistance QTL.

\subsubsection{The Genetics of Ear Rot Resistance}

\section{Fusarium Ear Rot}

Fusarium ear rot, caused by the fungi Fusarium verticillioides (Sacc.) Nirenberg (synonym $F$. moniliforme) and $F$. proliferatum (T. Matsushima), is extremely widespread and is associated with production of the fumonosin mycotoxin. QTL for resistance to ear rot have been mapped in four populations (Pérez-Brito et al., 2001; 
Robertson-Hoyt et al., 2006) and for resistance to fumonisin contamination in just two (Robertson-Hoyt et al., 2006). In all cases many, relatively small-effect QTL were found scattered throughout the genome. Evaluation of fumonisin levels in kernels is expensive and time consuming relative to evaluating levels of ear rot in the field. It has been reported that although phenotypic correlations between levels of ear rot and fumonsin are moderate to low (Clements et al., 2003, 2004), the genotypic correlations (the correlation observed after partitioning out non-genotypic effects due to environment and other factors) are significantly higher. Relatively high heritabilities for both traits have also been reported (Robertson et al., 2006). This implies that breeding for resistance to fumonisin contamination can be achieved by selection in multiple environments for resistance to fusarium ear rot. The composition of the maize kernel is a major determinant of fumonsin accumulation. Very little fumonsin accumulation was detected in kernels with low starch or where the amylase:amylopectin ration was high (Bluhm and Woloshuk, 2005).

\section{Aspergillus Ear Rot}

The primary cause of Aspergillus ear rot is the fungus Aspergillus flavus Link:Fr., which produces a mycotoxin called aflatoxin. Several studies have reported QTL for resistance to aflatoxin accumulation (Brooks et al., 2005; Busboom and White, 2004; Paul et al., 2003) and to Aspergillus ear rot (Busboom and White, 2004). In all cases high genotype/environment variation was observed and heritablities were low. In general most of QTL identified were of low to moderate effect, though two explained at least $20 \%$ of the phenotypic variation and were found in multiple environments (Brooks et al., 2005). This work suggests that, though difficult, it is possible to make progress in breeding for resistance to Aspergillus ear rot and aflatoxin accumulation. Indeed, several lines with enhanced aflatoxin accumulation resistance have been released (Williams et al., 2003).

A recent study showed high correlations, both phenotypic and especially genotypic, between Fusarium ear rot, Aspergillus ear rot and accumulation of aflatoxin and fumonisin in a set of recombinant inbred lines (Robertson-Hoyt et al., 2007). This suggests that common resistance mechanisms may function for the two diseases, and, conceivably, that breeding for Fusarium resistance may lead to a correlated response for Aspergillus resistance or vice-versa.

\section{Gibberella Ear Rot}

Gibberella ear rot is caused by the fungus Gibberella zeae (Schwein.) Petch (synonym Fusraium graminearum), which also produces several mycotoxins (Richard and Payne, 2002) including DON (deoxynivalenol, also known as vomitoxin). It has been shown that genetic variation for Gibberella ear rot resistance does exist (Chiang et al., 1987; Cullen et al., 1983; Hart et al., 1984; Schaafsma et al., 1997). One study (Ali et al., 2005) reported identification of 11 QTL for resistance to this disease but they were mostly small in effect and environmentally dependant. 


\section{Diplodia Ear Rot}

Diplodia ear rot (also known as Stenocarpella ear rot) is caused by Stenocarpella maydis (Berk.) (syn Diplodia maydis [Berk.]). Resistant lines have been reported (Rensburg et al., 2003) but no mapping studies of loci conferring resistance to this disease have been carried out. One report has suggested that non-additive genes are important for resistance (Olatinwo et al., 1999) while another suggested that both general and specific additive effects are significant (Dorrance et al., 1998). These contrasting results likely reflect the different germplasm under investigation in each study.

\subsection{The Genetics of Resistance to Foliar Diseases}

Of the major types of maize disease listed here, foliar diseases are by far the easiest to observe and to assess. This is likely the reason most of the maize QTL and genetic inheritance studies of disease resistance have used foliar pathogens. It also explains why breeders have made the most progress against foliar pathogens. QTL and inheritance studies for maize foliar disease resistance are too numerous to list here, but the reader is directed to two recent reviews (Pratt and Gordon, 2006; Wisser et al., 2006). Worldwide, the most damaging foliar diseases are probably gray leaf spot, northern corn leaf blight (also known as turcicum leaf blight) and southern rust.

\subsubsection{Gray Leaf Spot}

The causal agent of gray leaf spot is Cercospora zeae-maydis (Tehon and Daniels). This disease has increased in importance over the past 15 years due to increased practice of conservation tillage (Ward et al., 1999) which allows plant residue to remain on the soil surface and act as a spore reservoir. Gray leaf spot is probably the major foliar disease problem in the United States and in sub-saharan Africa. In general, resistance has been reported to be moderate to highly heritable and based largely on additive effects (Gevers et al., 1994; Gordon et al., 2006; Thompson et al., 1987). Several studies have identified QTL for gray leaf spot resistance (Bubeck et al., 1993; Clements et al., 2000; Gordon et al., 2004; Lehmensiek et al., 2001; Saghai Maroof et al., 1996). There is also a report of a major gene for gray leaf spot resistance (Gevers and Lake, 1994), but a subsequent study contradicted this (Gordon et al., 2004).

\subsubsection{Northern Leaf Blight}

The causal agent of northern leaf blight is Exserohilum turcicum (Pass) K. J. Leonard and E. G. Suggs (teliomorph: Setosphaeria turcica [Luttrell] Leonard and Suggs). It is found in most maize growing areas that have high humidity combined with moderate temperatures. It is a significant problem in the north eastern United States, in 
sub-Saharan Africa and areas of China, Latin America and India (Adipala et al., 1995; Dingerdissen et al., 1996). The genetics of northern leaf blight resistance have been extensively studied and are the subject of a recent review (Welz and Geiger, 2000). Northern leaf blight is unusual among necrotrophic diseases in that several dominant or partially dominant qualitative genes have been described that confer race-specific resistance to it, including Ht1(Hooker, 1963), Ht2 (Hooker, 1977), Ht3 (Hooker, 1981), Htn 1 (also known as HtN, Gevers, 1975) and HtP (Ogliari et al., 2005). This anomaly might be explained by the fact that northern leaf blight is arguably a hemibiotroph rather than a straightforward nectrotroph. After leaf penetration, initial growth of E. turcicum is mostly intracellular (Knox-Davies, 1974) in the mesophyll and does not cause cell death. It is also noteworthy that, compared to most major resistance genes, the $H t$ genes seem to have unusually high environmental dependence, particularly with regard to light and temperature (Leath et al., 1987, 1990; Thakur et al., 1989a, 1989b) and they tend to confer delayed lesion development or sporulation phenotypes rather than complete resistance. It could be argued that the $H t$ genes are rather atypical plant major resistance genes and should be thought of as large-effect, race-specific QTL.

QTL for northern leaf blight resistance have been identified in at least nine different populations (Brewster et al., 1992; Dingerdissen et al., 1996; Schechert et al., 1999; Welz and Geiger, 2000; Welz et al., 1999a, 1999b; Wisser et al., 2006). They seem to be distributed throughout the genome and tend to be insensitive to light and temperature variations (Carson and Van Dyke, 1994). Combinations of qualitative and quantitative resistance genes are generally employed in breeding for resistance, with the emphasis now on quantitative genes, due to their higher phenotypic stability (Pratt and Gordon, 2006).

\subsubsection{Southern Rust}

Southern rust is caused by the biotrophic fungus Puccinia polysora Underw.. It is a significant problem in Brazil and South America and is an intermittent but increasing problem in the United States. Rpp9 a major gene for southern rust resistance has been mapped to the short arm of chromosome 10 (Scheffer and Ullstrup, 1965). Other major genes for southern rust resistance have also been mapped to this region (Chen et al., 2004; Holland et al., 1998; Jines et al., 2006; Liu et al., 2003; Scott et al., 1984; Ullstrup, 1965) but their allelic relationships to Rpp9 have not been established. QTL for southern rust have been mapped in three populations (Brunelli et al., 2002; Holland et al., 1998; Jiang et al., 1999) with no colocalization of QTL across studies (Wisser et al., 2006).

The infrequent occurrence of southern rust in the United States has resulted in difficulties in breeding for durable resistance and most probably the loss of minor resistance alleles (Davis et al., 1990). While major genes have been effective so far (Pratt and Gordon, 2006), it would appear that in the absence of constant disease pressure, the use of marker assisted selection (MAS) would be a feasible approach. 


\section{Systemic Acquired Resistance and Induced Systemic Resistance in Maize}

Plants previously infected by a microorganism may become systemically more resistant to subsequent pathogen attack. Two types of systemic responses have been extensively characterized in dicotyledonous systems; systemic acquired resistance (SAR) and induced systemic resistance (ISR). SAR is a response to necrotizing pathogens and confers a broad-spectrum resistance. It is associated with induction of a number of pathogenesis-related (PR) genes and the NPRI gene has been shown to be a key regulator of the process (Grant and Lamb, 2006). Salicylic acid (SA) appears to be the local inducer of SAR and methyl salicylate (MS) has been implicated as the mobile signal which induces SAR systemically (Park et al., 2007). It is thought that MS is produced at the site(s) of infection, transported throughout the plant in the phloem and is converted to $\mathrm{SA}$ at the site of action. ISR is induced by symbiotic micro-organisms in the rhizosphere (Vallad and Goodman, 2004). It also confers broad-spectrum resistance but the pathway is regulated by jasmonate and ethylene rather than SA and PR-genes are not induced.

The SAR and ISR pathways have been extensively characterized in dicotyledonous systems but the presence of analogous pathways in monocotyledonous systems has not been conclusively proven. Still there is a significant amount of evidence to suggest that monocotyledonous responses similar to ISR and SAR do indeed exist. For instance, NPRI seems to function similarly in rice and Arabidopsis (Chern et al., 2001, 2005; Dong, 2004) and inducers of SAR function in several monocotyledonous species including maize (Gorlach et al., 1996; Kogel and Huckelhoven, 1999; Morris et al., 1998). SAR has also been shown to function in a field context on wheat (Calonnec et al., 1996). An ISR-like response has recently been documented in maize in response to the fungal root colonizing fungus Trichoderma virens (Djonovic et al., 2007).

On the other hand no change in disease responses was observed when the maize ortholog of NPRI was disrupted or over-expressed (Johal et al., unpublished), in contrast to the results in rice (see above). Similarly, whereas SA is a critical signal in Arabidopsis for expression of multiple modes of resistance, it seems to have little or no effect on the interaction of maize with pathogens, based on the analysis of both SA-deficient and SA over-accumulating transgenic maize (Johal and Yalpani, unpublished). Furthermore, in experiments in maize with common rust, prior or simultaneous inoculation of an incompatible race seemed to have no effect on the subsequent host reaction to a compatible race of the pathogen (S. Hulbert, pers.com)." In conclusion, it seems clear that while aspects of induced resistance responses are conserved between dicotyledonous and monocotyledonous systems, the responses are not the same. Furthermore it may be that the mechanisms associated with induced responses vary between monocotyledonous species. 


\section{The Future}

\subsection{Prospects for Genetically Engineered Plant Disease Resistance in Maize}

Despite a substantial amount of effort over more than a decade, there are no commercially available transgenic plants conferring increased levels of fungal or bacterial disease resistance. While there are many examples of transgenic plants with increased disease resistance (e.g., Gao et al., 2000, 2007; Grison et al., 1996), none have become viable commercial products (Gurr and Rushton, 2005b; Hammond-Kosack and Parker, 2003). There are many reasons for this lack of success, including growth penalties conferred by the precocious or over-activation of defense responses, presumably due to the redirection of cellular metabolism towards defense and away from growth (Logemann et al., 1995). In other cases, regulatory or economic factors have been the main stumbling blocks.

New technologies and knowledge may eventually facilitate the production of commercially viable disease-resistant transgenic plants. More precise control of gene expression, through the genomics-based discovery and use of pathogenesisinducible natural and synthetic promoters has some potential (Gurr and Rushton, 2005a). The use of gene-shuffling techniques to produce novel disease resistance specificities (Bernal et al., 2005) or to produce novel enzymes (Duvick, 2001) also holds great promise. Perhaps most excitingly, the use of RNAi to inhibit specific, genes in the pathogen offers an almost unlimited number of essential pathogenesis pathways to target. In these cases, a double-stranded RNA (dsRNA) molecule, complementary to a specific pathogen gene would be expressed in the host and transferred to the pathogen during infection to silence specific genes. The effective transfer of the dsRNA from host to pathogen remains the main problem but there are indications that this is not insurmountable, at least in some systems (Bailey et al., 2006; Lilley et al., 2007).

The sheer economic value of maize, makes it an attractive target for some of these approaches. In many crops the economic value of transgenic disease resistance would be derived from the resulting reduction in pesticide applications. In maize, with the exception of seed treatments, pesticide applications to control disease are uncommon due to the low margin of profitability (Smith and White, 1988). In this case, economic value would likely have to be derived from increased yield or quality. Diseases for which conventional breeding has not produced entirely adequate solutions would be the main targets, including Aspergillus and Fusarium ear rots (Duvick, 2001) and grey leaf spot. In 2007 an unprecedented proportion of maize acreage in the mid-western U.S.A, about 15-20\%, was sprayed with foliar fungicides (Gary Munkvold pers.com). This was due to the high price of corn making such treatments economically viable and it is likely to prove the exception. 


\subsection{Maize as a System for Disease Resistance Genetics Studies}

Maize was for many years at the forefront of plant disease resistance genetics research (see above). It has somewhat fallen out of favor as a model system in recent years as Arabidopsis, tomato and rice have been more utilized in the public sphere. Disease resistance research in maize has been pursued most vigorously in the private sector.

We feel that maize is again becoming an attractive system for plant disease resistance genetics, both as a model system and as a target in its own right. The maize genome sequence should be finished as this book is published and other resources for fine scale mapping, such as the intermated B73/Mo17 (IBM population (Balint-Kurti et al., 2007), and the 5000-line nested association-mapping (NAM) population (Holland, Buckler personal communication) are becoming available. Furthermore, systematic mutagenesis within maize should also be more feasible with the development of large collections of transposon insertion lines in a uniform genetic background (http://www.plantgdb.org/prj/AcDsTagging/) These new resources can be combined with the existing beneficial features of maize such as its wide genetic diversity and ease of crossing and with the genetic stocks and resources that have been built up over many years of research.

For some important diseases there is no appropriate surrogate system for studying maize's interaction with pathogens. Examples include ear and stalk rots of the ear and the stalk, maize smut that causes tumors on many parts of the plant, and crazy top disease (caused by a downy mildew pathogen) that interferes with maize's transition to flowering (Figure 1, Agrios, 1997). The fact that maize is such an
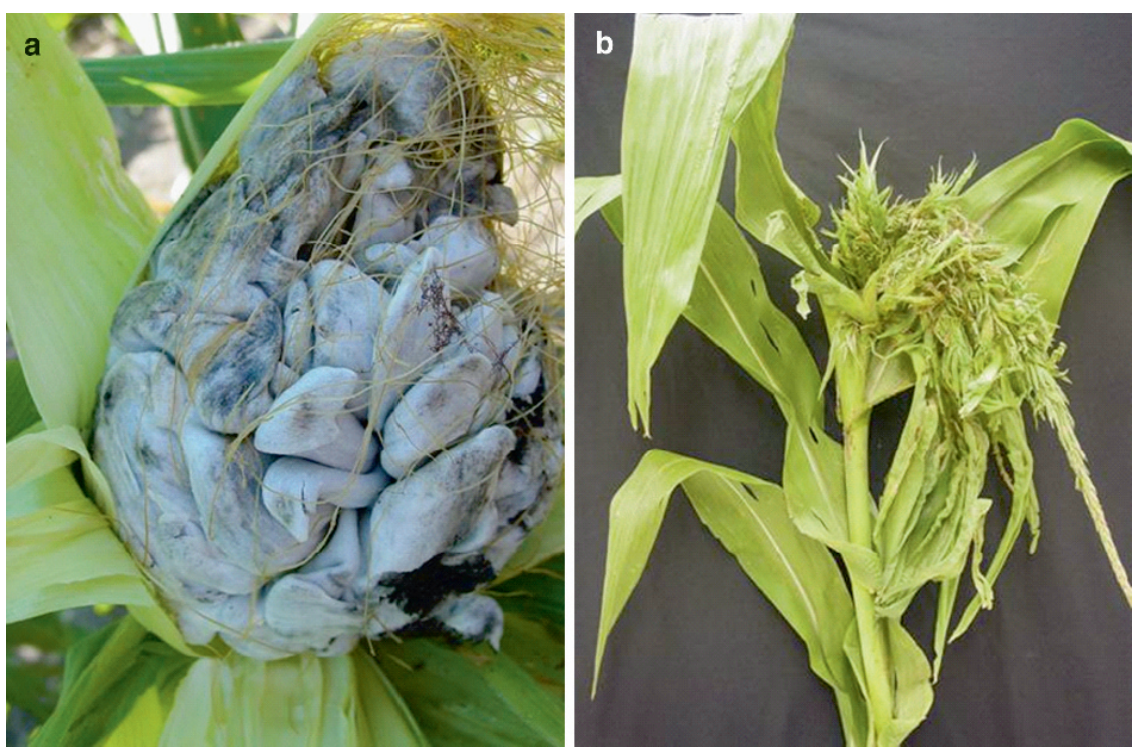

Fig. 1 Examples of diseases unique to maize, common smut (A) and crazy top (B) 
important crop means that findings made in maize can be directly useful as well as providing a framework for disease resistance studies in other species. Its significance as a model plant may increase in the future, given that most energy crop plants proposed for biomass production are, like maize, $\mathrm{C} 4$ grasses.

In particular, maize is a superior system for the investigation of quantitative traits. In many cases quantitative disease resistance appears to be durable and the assumption is that it incurs few growth penalties- though this has not been rigorously tested (Brown, 2002). Furthermore, there is evidence that in some cases quantitative resistance confers resistance to a wide spectrum of pathogens (Mitchell-Olds et al., 1995, Balint-Kurti et al., unpublished). It may be that the cloning and manipulation of quantitative resistance genes will ultimately prove the most effective transgenic approach to disease resistance.

Acknowledgements We would like to thank Bill Dolezal, Judith Kolkman, and Randy Wisser for helpful discussions regarding preparation of this chapter

\section{References}

Adipala, E., J.P. Takan, and M.W. Ogenga-Latigo. 1995. Effect of planting density of maize on the progress and spread of northern leaf blight from Exserohilum turcicum infested residue source, pp. 25, In E. Adipala, (ed.) European Journal of Plant Pathology, Vol. 101.

Agrios, G.N. 1997. Plant Pathology. Fourth edition. Academic Press. San Diego.

Ali, M.L., J.H. Taylor, L. Jie, G. Sun, M. William, K.J. Kasha, L.M. Reid, and K.P. Pauls. 2005. Molecular mapping of QTLs for resistance to Gibberella ear rot, in corn, caused by Fusarium graminearum. Genome 48:521-533.

Avila, C.-M., Z. Satovic, J.-C. Sillero, D. Rubiales, M.-T. Moreno, and K.P. PaulsA.-M. Torres. 2004. Isolate and organ-specific QTLs for ascochyta blight resistance in faba bean (Vicia faba L). Theoretical and Applied Genetics 108:1071-1078.

Badu-Apraku, B., V.E. Gracen, and G.C. Bergstrom. 1987a. A major gene for resistance to anthracnose stalk rot in maize. Phytopathology 77:957-959.

Badu-Apraku, B., V.E. Gracen, and G.C. Bergstrom. 1987b. Inheritance of resistance to anthracnose stalk rot and leaf blight in a maize inbred derived from a temperate by tropical germplasm combination, pp. 221, In B. Badu-Apraku, (ed.) Maydica, Vol. 32.

Bailey, A.M., Niblett, C.L., and A.S. Csinos. 2006. Controlling the black shank disease of tobacco by silencing the cutinase gene in the pathogen, Phytophthora parasitica var. nicotianae. Phytopathology 96:S7.

Balint-Kurti, P.J., J.C. Zwonitzer, R.J. Wisser, M.L. Carson, M. Oropeza-Rosas, J.B. Holland, and S.J. Szalma. 2007. Precise mapping of quantitative trait loci for resistance to southern leaf blight, caused by Cochliobolus heterostrophus race $\mathrm{O}$, and flowering time using advanced intercross maize lines. Genetics 176:645-657.

Bennetzen, J.L., W.E. Blevins, and A.H. Ellingboe. 1988. Cell-autonomous recognition of the rust pathogen determines Rp1-specified resistance in maize. Science 241:208-210.

Bluhm, B.H., and C.P. Woloshuk. 2005. Amylopectin induces fumonisin B1 production by fusarium verticillioides during colonization of maize kernels, pp. 1333, In B. H. Bluhm, (ed.) Molecular Plant-Microbe Interactions, Vol. 18.

Bradley, D.J., G.S. Gilbert, and I.M. Parker. 2003. Susceptibility of clover species to fungal infection: The interaction of leaf surface traits and environment. American Journal of Botany 90:857-864. 
Brewster, V.A., M.L. Carson, and Z.W. WicksIII, . 1992. Mapping components of partial resistance to northern leaf blight of maize using reciprocal translocation. Phytopathology 82:225-229.

Broglie, K., K. Butler, A. Conceicao, T. Frey, J. Hawk, D. Multani, and P. Wolters. 2006. Polynucleotides and methods for making plants resistant to fungal pathogens. USA 2006.

Brooks, T.D., W.P. Williams, G.L. Windham, M.C. Willcox, and K.P. PaulsH.K. Abbas. 2005. Quantitative trait loci contributing resistance to aflatoxin accumulation in the maize inbred Mp313E. Crop Science 45:171-174.

Brown, J.K.M. 2002. Yield penalties of disease resistance in crops. Current Opinion in Plant Biology 5:339-344.

Brunelli, K.R., H.P. Silva, and L.E. Aranha-Camargo. 2002. Mapeamento de genes de resistencia quantitativa a Puccinia polysora em milho. Fitopatologia Brasileira 27:134-140.

Bubeck, D.M., M.M. Goodman, W.D. Beavis, and D. Grant. 1993. Quantitative trait loci controlling resistance to gray leaf spot in maize. Crop Science 33:838-847.

Buckler, E.S., J.M. Thornsberry, and S. Kresovich. 2001. Molecular diversity, structure and domestication of grasses. Genetical Research 77:213-218.

Buckler, E.S., B.S. Gaut, and M.D. McMullen. 2006. Molecular and functional diversity of maize. Current Opinion in Plant Biology 9:172-176.

Busboom, K.N., and D.G. White. 2004. Inheritance of resistance to aflatoxin production and Aspergillus ear rot of corn from the cross of inbreds B73 and Oh516. Phytopathology 94:1107-1115.

Calenge, F., A. Faure, M. Goerre, C. Gebhardt, W.-E. Van-de-Weg, L. Parisi, and C.-E. Durel. 2004. Quantitative trait loci (QTL) analysis reveals both broad-spectrum and isolate-specific QTL for scab resistance in an apple progeny challenged with eight isolates of Venturia inaequalis. Phytopathology 94:370-379.

Calonnec, A., H. Goyeau, and C.D. Vallavieille-Pope. 11996. Effects of induced resistance on infection efficiency and sporulation of Puccinia striiformis on seedlings in varietal mixtures and on field epidemics in pure stands. European Journal of Plant Pathology 102:733-741.

Carson, M.L., and A.L. Hooker. 1981. Inheritance of resistance to stalk rot of corn caused by Colletotrichum graminicola, pp. 1190, In M. L. Carson, (ed.) Phytopathology, Vol. 71.

Carson, M.L., and C.G. Van Dyke. 1994. Effect of light and temperature on expression of partial resistance of maize to Exserohilum turcicum. Plant Disease 78:519-522.

Chang, R.-Y., and P.-A. Peterson. 1995. Genetic control of resistance to Bipolaris maydis: One gene or two genes? Journal of Heredity 86:94-97.

Chen, C.X., Z.L. Wang, D.E. Yang, C.J. Ye, Y.B. Zhao, D.M. Jin, M.L. Weng, and B. Wang. 2004. Molecular tagging and genetic mapping of the disease resistance gene RppQ to southern corn rust. Theoretical and Applied Genetics 108:945-950.

Chern, M.S., H.A. Fitzgerald, R.C. Yadav, P.E. Canlas, X. Dong, and K.P. PaulsP.C. Ronald. 2001. Evidence for a disease-resistance pathway in rice similar to the NPR1-mediated signaling pathway in Arabidopsis. Plant Journal 27:101-113.

Chern, M., H.A. Fitzgerald, P.E. Canlas, D.A. Navarre, and P.C. Ronald. 2005. Overexpression of a rice NPR1 homolog leads to constitutive activation of defense response and hypersensitivity to light. Molecular Plant-Microbe Interactions 18:511-520.

Chiang, M.S., M. Hudon, A. Devaux, and I. Ogilvie. 1987. Inheritance of resistance to Gibberella ear rot in maize, pp. 29, In M. S. Chiang, (ed.) Phytoprotection, Vol. 68.

Choi, S.H., S.K. Green, D.R. Lee, and J.Y. Yoon. 1989. Incompletely dominant single resistance gene for peanut stripe virus in soybean line AGS 129. Euphytica V40:193-196.

Ciuffetti, L.M., M.R. Pope, L.D. Dunkle, J.M. Daly, and H.W. Knoche. 1983. Isolation and structure of an inactive product derived from the host-specific toxin produced by Helminthosporium carbonum. Biochemistry 22:3507-3510.

Clay, K., and P.X. Kover. 1996. The red queen hypothesis and plant/pathogen interactions. Annual Review of Phytopathology 34:29-50.

Clements, M.J., J.W. Dudley, and D.G. White. 2000. Quantitative trait loci associated with resistance to gray leaf spot of corn. Phytopathology 90:1018-1025.

Clements, M.J., K.W. Campbell, C.M. Maragos, C. Pilcher, J.M. Headrick, J.K. Pataky, and D.G. White. 2003. Influence of Cry $1 \mathrm{Ab}$ protein and hybrid genotype on fumonisin contamination and fusarium ear rot of corn. Crop Science 43:1283-1293. 
Clements, M.J., C.M. Maragos, J.K. Pataky, and D.G. White. 2004. Sources of resistance to fumonisin accumulation in grain and fusarium ear and kernel rot of corn. Phytopathology 94:251-260.

Cullen, D., R.W. Caldwell, and E.B. Smalley. 1983. Susceptibility of maize to Gibberella zeae ear rot: Relationship to host genotype, pathogen virulence, and zearalenone contamination. Plant Disease 67:89-91.

Davis, D.W., C.A. Engelkes, and J.V. Groth. 1990. Erosion of resistance to common leaf rust in exotic-derived maize during selection for other traits. Phytopathology 80:339-342.

Dean, J.D., P.H. Goodwin, and T. Hsiang. 2005. Induction of glutathione S-transferase genes of Nicotiana benthamiana following infection by Colletotrichum destructivum and C. orbiculare and involvement of one in resistance. Journal of Experimental Botany 56:1525-1533.

Dingerdissen, A.L., H.H. Geiger, M. Lee, A. Schechert, and H.G. Welz. 1996. Interval mapping of genes for quantitative resistance of maize to Setosphaeria turcica, cause of northern leaf blight, in a tropical environment. Molecular Breeding 2:143-156.

Djonovic, S., W.A. Vargas, M.V. Kolomiets, M. Horndeski, A. Wiest, and C.M. Kenerley. 2007. A proteinaceous elicitor Sm1 from the beneficial fungus trichoderma virens is required for induced systemic resistance in maize. Plant Physiology (In Press).

Doebley, J., A. Stec, and L. Hubbard. 1997. The evolution of apical dominance in maize. Nature London 386:485-488.

Dong, X. 2004. NPR1, all things considered. Current Opinion in Plant Biology 7:547-552.

Dorrance, A.E., K.H. Hinkelmann, and H.L. Warren. 1998. Diallel analysis of diplodia ear rot resistance in maize. Plant Disease 82:699-703.

Duvick, J. 2001. Prospects for reducing fumonisin contamination of maize through genetic modification. Environmental Health Perspectives 109 S2:337-342.

Ellis, J., P. Dodds, and T. Pryor. 2000. Structure, function and evolution of plant disease resistance genes. Current Opinion in Plant Biology 3:278-284.

Gao, A.-G., S.M. Hakimi, C.A. Mittanck, Y. Wu, B.M. Woerner, D.M. Stark, D.M. Shah, J. Liang, and C.M.T. Rommens. 2000. Fungal pathogen protection in potato by expression of a plant defensin peptide. Nature Biotechnology 18:1307-1310.

Gao, X., W.B. Shim, C. Go?bel, S. Kunze, I. Feussner, R. Meeley, P. Balint-Kurti, and M. Kolomiets. 2007. Disruption of a maize 9-lipoxygenase results in increased resistance to fungal pathogens and reduced levels of contamination with mycotoxin fumonisin. Molecular Plant-Microbe Interactions 20:922-933.

Gebhardt, C., and J.P.T. Valkonen. 2001. Organization of genes controlling disease resistance in the potato genome. Annual Review of Phytopathology 39:79-102.

Gevers, H.O. 1975. A new major gene for resistance to Helminthosporium turcicum leaf blight of maize, pp. 296-299 Plant disease reporter.

Gevers, H.O., and J.K. Lake. 1994. GLS1: A major gene for resistance to grey leaf spot in maize. South African Journal of Science 90:377-379.

Gevers, H.O., J.K. Lake, and T. Hohls. 1994. Diallel cross analysis of resistance to gray leaf spot in maize. Plant Disease 78:379-383.

Glazebrook, J. 2005. Contrasting mechanisms of defense against biotrophic and necrotrophic pathogens. Annual Review of Phytopathology 43:205-227.

Gordon, S.-G., M. Bartsch, I. Matthies, H.-O. Gevers, P.-E. Lipps, and R.-C. Pratt. 2004. Linkage of molecular markers to Cercospora zeae-maydis resistance in maize. Crop Science 44:628-636.

Gordon, S.G., P.E. Lipps, and R.C. Pratt. 2006. Heritability and components of resistance to Cercospora zeae-maydis derived from maize inbred VO613Y. Phytopathology 96:593-598.

Gorlach, J., S. Volrath, G. Knauf-Beiter, G. Hengy, U. Beckhove, K.H. Kogel, M. Oostendorp, T. Staub, E. Ward, H. Kessmann, and J. Ryals. 1996. Benzothiadiazole, a novel class of inducers of systemic acquired resistance, activates gene expression and disease resistance in wheat, pp. 629, In J. Gorlach, (ed.) Plant Cell, Vol. 8.

Grant, M., and C. Lamb. 2006. Systemic immunity, pp. 414, In M. Grant, (ed.) Current Opinion in Plant Biology, Vol. 9.

Grison, R., B. Grezes-Besset, M. Schneider, N. Lucante, L. Olsen, J.-J. Leguay, and A. Toppan. 1996. Field tolerance to fungal pathogens of Brassica napus constitutively expressing a chimeric chitinase gene. Nature Biotechnology 14:643-646. 
Gurr, S.J., and P.J. Rushton. 2005a. Engineering plants with increased disease resistance: How are we going to express it? Trends in Biotechnology 23:283-290.

Gurr, S.J., and P.J. Rushton. 2005b. Engineering plants with increased disease resistance: What are we going to express? Trends in Biotechnology 23:275-282.

Hammond-Kosack, K.E., and J.D.G. Jones. 1993. Incomplete dominance of tomato Cf genes for resistance to Cladosporium fulvum. Molecular Plant-Microbe Interactions 7:58-70.

Hammond-Kosack, K.E., and J.E. Parker. 2003. Deciphering plant-pathogen communication: Fresh perspectives for molecular resistance breeding. Current Opinion in Biotechnology 14:177-193.

Hart, L.P., E. Gendloff, and E.C. Rossman. 1984. Effect of corn genotypes on ear rot infection by Gibberella zeae. Plant Disease 68:296-298.

Holland, J.B., D.V. Uhr, D. Jeffers, and M.M. Goodman. 1998. Inheritance of resistance to southern corn rust in tropical-by-corn-belt maize populations. Theoretical and Applied Genetics 96:232-241.

Hooker, A.L. 1956. Association of resistance to several seedling root, stalk, and ear diseases in Corn, pp. 379, In A. L. Hooker, (ed.) Phytopathology, Vol. 46.

Hooker, A.L. 1963. Inheritance of chlorotic-lesion resistance to Helminthosporium turcicum in seedling corn, pp. 660, In A. L. Hooker, (ed.) Phytopathology, Vol. 53.

Hooker, A.L. 1977. A second major gene locus in corn for chlorotic-lesion resistance to Helminthosporium turcicum, pp. 132, In A. L. Hooker, (ed.) Crop Science, Vol. 17.

Hooker, A.L. 1981. Resistance to Helminthosporium turcicum from Tripsacum floridanum incorporated into corn, pp. 87, In A. L. Hooker, (ed.) Maize Genetics Cooperation News Letter.

Hu, G., and S.H. Hulbert. 1994. Evidence for the involvement of gene conversion in meiotic instability of the Rp1 rust resistance genes of maize. Genome 37:742-746.

Hu, G., T.E. Richter, S.H. Hulbert, and T. Pryor. 1996. Disease lesion mimicry caused by mutations in the rust resistance gene rp1. Plant Cell 8:1367-1376.

Hulbert, S.H. 1997. Structure and evolution of the rp1 complex conferring rust resistance in maize. Annual Review of Phytopathology 35:293-310.

Hulbert, S., C.A. Webb, S.M. Smith, Q. Sun. 2001. Resistance gene complexes: Evolution and utilization. Annual Review of Phytopathology 39:285-312.

Jiang, J.C., G.O. Edmeades, I. Armstead, H.R. Lafitte, M.D. Hayward, and D. Hoisington. 1999. Genetic analysis of adaptation differences between highland and lowland tropical maize using molecular markers. Theoretical and Applied Genetics 99:1106-1119.

Jines, M.P., P. Balint-Kurti, L.A. Robertson-Hoyt, T.L. Molnár, J. Holland, and M.M. Goodman. 2006. Mapping resistance to southern rust in a tropical by temperate maize recombinant inbred topcross population. Theoretical and Applied Genetics (in press).

Johal, G.S., and S.P. Briggs. 1992. Reductase activity encoded by the HM1 disease resistance gene in maize. Science 258:985-7.

Jung, M., T. Weldekidan, D. Schaff, A. Paterson, S. Tingey, and J. Hawk. 1994. Generation-means analysis and quantitative trait locus mapping of anthracnose stalk rot genes in maize. Theoretical and Applied Genetics 89:413-418.

Kappelman, A.J.J., and D.L. Thompson. 1966. Inheritance of resistance to Diplodia stalk-rot in corn, pp. 288, In A. J. J. Kappelman, (ed.) Crop Sci., Vol. 6.

Kawai, M., D.H. Rich, and J.D. Walton. 1983. The structure and conformation of HC-toxin. Biochemical and Biophysical Research Communications 111:398-403.

Knox-Davies, P.S. 1974. Penetration of maize leaves by Helminthosporium turcicum. Phytopathology 64:1468-70.

Kogel, K.H., and R. Huckelhoven. 1999. Superoxide generation in chemically activated resistance of barley in response to inoculation with the powdery mildew fungus, pp. 1, In K. H. Kogel, (ed.) Journal of Phytopathology, Vol. 147.

Leath, S., R.P. Thakur, and K.J. Leonard. 1987. Effects of temperature and light on reaction of corn to race 3 of Exserohilum turcicum, pp. 1737, In S. Leath, (ed.) Phytopathology, Vol. 77.

Leath, S., R.P. Thakur, and K.J. Leonard. 1990. Variation in expression of monogenic resistance in corn to Exserohilum turcicum race 3 under different temperature and light regimes. Phytopathology 80:309-313. 
Lehmensiek, A., A.-M. Esterhuizen, D. van-Staden, S.-W. Nelson, and K.P. PaulsA.-E. Retief. 2001. Genetic mapping of gray leaf spot (GLS) resistance genes in maize. Theoretical and Applied Genetics 103:797-803.

Levine, A., R. Tenhaken, R. Dixon, and C. Lamb. 1994. H2O2 from the oxidative burst orchestrates the plant hypersensitive disease resistance response. Cell 79:583-593.

Levings, C.S.3rd, . 1990. The Texas Cytoplasm of Maize: Cytoplasmic Male Sterility and Disease Susceptibility. Science 250:942-947.

Levings, C.S. 3rd, and J.N. Siedow. 1992. Molecular basis of disease susceptibility in the Texas cytoplasm of maize. Plant Molecular Biology 19:135-47.

Li, Z.K., L.J. Luo, H.W. Mei, A.H. Paterson, X.H. Zhao, D.B. Zhong, Y.P. Wang, X.Q. Yu, L. Zhu, R. Tabien, J.W. Stansel, and C.S. Ying. 1999. A "defeated" rice resistance gene acts as a QTL against a virulent strain of Xanthomonas oryzae pv. oryzae. Molecular and General Genetics 261:58-63.

Lilley, C.J., M. Bakhetia, W.L. Charlton, and P.E. Urwin. 2007. Recent progress in the development of RNA interference for plant parasitic nematodes. Molecular Plant Pathology 8:701-711.

Liu, Z.X., S.C. Wang, J.R. Dai, L.J. Huang, and H.H. Cao. 2003. Studies of genetic analysis and SSR linked marker location of gene resistance to southern rust in inbred line P25 of maize. Acta Genetica Sinica 30:706-710.

Logemann, E., S.-C. Wu, J. Schroder, E. Schmelzer, I.E. Somssich, and K.P. PaulsK. Hahlbrock. 1995. Gene activation by UV light, fungal elicitor or fungal infection in Petroselinum crispum is correlated with repression of cell cycle-related genes. The Plant Journal 8:865-876.

Martin, G.B., A.J. Bogdanove, and G. Sessa. 2003. Understanding the functions of plant disease resistance proteins. Annual Review of Plant Biology 54:23-61.

McDowell, J.M., and S.A. Simon. 2006. Recent insights into R gene evolution. Molecular Plant Pathology 7:437-448.

Meeley, R., and J. Walton. 1993. Molecular biology and biochemistry of Hm1, a maize gene for fungal resistance. Kulwer Academic Press, Dordrecht.

Meeley, R.B., G.S. Johal, S.P. Briggs, J.D. Walton. 1992. A biochemical phenotype for a disease resistance gene of maize. Plant Cell 4:71-77.

Meyers, B.C., A. Kozik, A. Griego, H. Kuang, and R.W. Michelmore. 2003. Genome-wide analysis of NBS-LRR-encoding genes in arabidopsis. Plant Cell 15:809-834.

Milligan, S.B., J. Bodeau, J. Yaghoobi, I. Kaloshian, P. Zabel, and V.M. Williamson. 1998. The root knot nematode resistance gene Mi from tomato is a member of the leucine zipper, nucleotide binding, leucine-rich repeat family of plant genes. Plant Cell 10:1307-1320.

Mitchell-Olds, T., R.V. James, M.J. Palmer, and P.H. Williams. 1995. Genetics of Brassica rapa (syn. campestris). 2. Multiple disease resistance to three fungal pathogens: Peronospora parastica, Albugo candida and Leptosphaeria maculans. Heredity 75:362-369.

Monosi, B., R.-J. Wisser, L. Pennill, and S.-H. Hulbert. 2004. Full-genome analysis of resistance gene homologues in rice. Theoretical and Applied Genetics 109:1434-1447.

Morris, S.W., B. Vernooij, S. Titatarn, M. Starrett, S. Thomas, C.C. Wiltse, R.A. Frederiksen, A. Bhandhufalck, S. Hulbert, and S. Uknes. 1998. Induced resistance responses in maize. Molecular Plant Microbe Interactions 11:643-658.

Multani, D.S., R.B. Meeley, A.H. Paterson, J. Gray, S.P. Briggs, and G.S. Johal. 1998. Plantpathogen microevolution: Molecular basis for the origin of a fungal disease in maize. Proceedings of the National Academy of Sciences of the United States of America 95:1686-91.

Nelson, O.E., and A.J. Ullstrup. 1964. Resistance to leaf spot in maize; genetic control of resistance to Helminthosporium carbonum Ull. Journal of Heredity 55:195-199.

Nyhus, K.A., W.A. Russell, W.D. Guthrie, and C.A. Martinson. 1989. Reaction of two maize synthetics to anthracnose stalk rot and northern corn leaf blight following recurrent selection for resistance to Diplodia stalk rot and European corn borer. Phytopathology 79:166-169.

Oerke, E.C. 2005. Crop losses to pests. The Journal of Agricultural Science 144:31-43.

Ogliari, J.B., M.A. Guimaraes, and I.O. Geraldi. 2005. New resistance genes in the Zea maysExserohilu turcicum pathosystem. Genetics and Molecular Biology 28:435-439. 
Olatinwo, R., K. Cardwell, A. Menkir, M. Deadman, and A. Julian. 1999. Inheritance of resistance to Stenocarpella macrospora (Earle) ear rot of maize in the mid-altitude zone of Nigeria. European Journal of Plant Pathology 105:535-543.

Parisy, V., B. Poinssot, L. Owsianowski, A. Buchala, J. Glazebrook, and F. Mauch. 2007. Identification of PAD2 as a gamma-glutamylcysteine synthetase highlights the importance of glutathione in disease resistance of Arabidopsis. The Plant Journal 49:159-172.

Park, S.-W., E. Kaimoyo, D. Kumar, S. Mosher, and D.F. Klessig. 2007. Methyl salicylate is a critical mobile signal for plant systemic acquired resistance. Science 318:113-116.

Parker, I.M., and G.S. Gilbert. 2004. The evolutionary ecology of novel plant-pathogen interactions. Annual Review of Ecology, Evolution, and Systematics 35:675-700.

Parlevliet, J.-E. 2002. Durability of resistance against fungal, bacterial and viral pathogens; present situation. Euphytica 124:147-156.

Paul, C., G. Naidoo, A. Forbes, V. Mikkilineni, D. White, and T. Rocheford. 2003. Quantitative trait loci for low aflatoxin production in two related maize populations. Theoretical and Applied Genetics 107:263-270.

Pè, M.-E., L. Gianfranceschi, G. Taramino, R. Tarchini, P. Angelini, M. Dani, and G. Binelli. 1993. Mapping quantitative trait loci (QTLs) for resistance to Gibberella zeae infection in maize. Molecular and General Genetics 241:11-16.

Pérez-Brito, D., D. Jeffers, D. Gonzales-de-León, M. Khairallah, M. Cortes-Cruz, G. VelásquezCardelas, S. Azpiroz-Rivero, and G. Srinivasan. 2001. Cartografia de QTL de la resistencia a la pudrición de la mazorca (Fusarium moniliforme) en maiz de Valles Altos, México. Agrociencia 35:181-196.

Piperno, D.R., and K.V. Flannery. 2001. The earliest archaeological maize (Zea mays L.) from highland Mexico: New accelerator mass spectrometry dates and their implications. Proceedings of the National Academy of Sciences of the United States of America 98:2101-3.

Pratt, R.C., and S.G. Gordon. 2006. Breeding for resistance to maize foliar pathogens. Plant Breeding Reviews 27:119-173.

Pring, D.R., and D.M. Lonsdale. 1989. Cytoplasmic male sterility and maternal inheritance of disease susceptibility in maize. Annual Review of Phytopathology 27:483-502.

Pryor, A.J. 1987. The origin and structure of fungal disease resistance genes in plants. Trends in Genetics 3:157-161.

Qi, X., G. Jiang, W. Chen, R.-E. Niks, P. Stam, and P. Lindhout. 1999. Isolate-specific QTLs for partial resistance to Puccinia hordei in barley. Theoretical and Applied Genetics 99:877-884.

Ramakrishna, W., J. Emberton, M. Ogden, P. SanMiguel, and J.L. Bennetzen. 2002. Structural analysis of the maize Rp1 complex reveals numerous sites and unexpected mechanisms of local rearrangement. Plant Cell 14:3213-3223.

Reeves, R.G. 1950. Morphology of the ear and tassel of maize. American Journal of Botany 37:697-704.

Rensburg, J.B.J.V., J.D. Rossouw, and C.S.V. Deventer. 2003. New generation maize inbred lines resistant to diplodia ear rot, caused by Stenocarpella maydis (Berk) Sutton, pp. 127, In J. B. J. v. Rensburg, (ed.) South African Journal of Plant and Soil, Vol. 20.

Richard, J.L., and G.A. Payne. 2002. Mycotoxins: Risks in Plant, Animal and Human Systems. Task Force report Council for Agricultural Science and Technology, Ames, Iowa, USA.

Richter, T.E., T.J. Pryor, J.L. Bennetzen, and S.H. Hulbert. 1995. New rust resistance specificities associated with recombination in the Rp1 complex in maize. Genetics 141:373-81.

Robertson, L.A., C.E. Kleinschmidt, D.G. White, G.A. Payne, C.M. Maragos, and J.B. Holland. 2006. Heritabilities and correlations of fusarium ear rot resistance and fumonisin contamination resistance in two maize populations. Crop Science 46:353-361.

Robertson-Hoyt, L.A., M.P. Jines, P.J. Balint-Kurti, C.E. Kleinschmidt, D.G. White, G.A. Payne, C.M. Maragos, T.L. Molnar, and J.B. Holland. 2006. QTL mapping for Fusarium ear rot and fumonisin contamination resistance in two maize populations. Crop Science 46:1734-1743.

Robertson-Hoyt, L.A., J. Betran, G.A. Payne, D.G. White, T. Isakeit, C.M. Maragos, T.L. Molnar, and J.B. Holland. 2007. Relationships among resistances to fusarium and aspergillus ear rots and contamination by fumonisin and aflatoxin in maize. Phytopathology 97:311-317.

Romer, P., S. Hahn, T. Jordan, T. Strauss, U. Bonas, and T. Lahaye. 2007. Plant pathogen recognition mediated by promoter activation of the pepper Bs3 resistance Gene. Science 318:645-648. 
Saghai Maroof, M.A., Y.G. Yue, Z.X. Xiang, E.L. Stromberg, and G.K. Rufener. 1996. Identification of quantitative trait loci controlling resistance to gray leaf spot disease in maize. Theoretical and Applied Genetics 93:539-546.

Schaafsma, A.W., R.W. Nicol, and L.M. Reid. 1997. Evaluating commercial maize hybrids for resistance to gibberella ear rot. European Journal of Plant Pathology 103:737-746.

Schechert, A.W., H.G. Welz, and H.H. Geiger. 1999. QTL for resistance to Setosphaeria turcica in tropical African maize. Crop Science 39:514-523.

Scheffer, R.P., and A.J. Ullstrup. 1965. A host-specific toxic metabolite from Helminthosporium carbonum. Phytopathology 55:1037-1038.

Scott, G.E., S.B. King, and J.W.J. Armour. 1984. Inheritance of resistance to southern corn rust in maize Zea-mays populations. Crop Science 24:265-267.

Smith, D.R., and D.G. White. 1988. Diseases of corn, p. 687-766, InG. F. Sprague and J. W. Dudley, eds. Corn and Corn Improvement, Vol. 18. American Society of Agronomy Inc., Madison, Wisconsin, U.S.A.

Smith, S.M., A.J. Pryor, and S.H. Hulbert. 2004. Allelic and haplotypic diversity at the rp1 rust resistance locus of maize. Genetics 167:1939-1947.

Smith, S.M.S.M., and S.H.S.H. Hulbert. 2005. Recombination events generating a novel Rp1 race specificity. Molecular Plant-Microbe Interactions 18:220-228.

Simmons, C.R., S. Grant, D.J. Altier, P.F. Dowd, O. Crasta, O. Folkerts, and N. Yalpani. 2001. Maize $\mathrm{rhm} 1$ resistance to bipolaris maydis is associated with few differences in pathogenesis-related proteins and global mRNA profiles. Molecular Plant-Microbe Interactions 14:947-954.

Steffenson, B.J. 1992. Analysis of durable resistance to stem rust in barley. Euphytica 63:153-167.

Stewart, H.E., J.E. Bradshaw, and B. Pande. 2003. The effect of the presence of R-genes for resistance to late blight (Phytophthora infestans) of potato (Solanum tuberosum) on the underlying level of field resistance. Plant Pathology 52:193-198.

Sudupak, M.A., J.L. Bennetzen, and S.H. Hulbert. 1993. Unequal exchange and meiotic instability of disease-resistance genes in the Rp1 region of maize. Genetics 133:119-125.

Talukder, Z.I., D. Tharreau, and A.H. Price. 2004. Quantitative trait loci analysis suggests that partial resistance to rice blast is mostly determined by race-specific interactions. New Phytologist 162:197-209.

Thakur, R.P., K.J. Leonard, and S. Leath. 1989a. Effects of temperature and light on virulence of Exserohilum turcicum on corn. Phytopathology 79:631-635.

Thakur, R.P., K.J. Leonard, and R.K. Jones. 1989b. Characterization of a new race of Exserohilum turcicum virulent on corn with resistance gene Ht N. Plant Disease 73:151-155.

Thompson, D.L., R.R. Bergquist, G.A. Payne, D.T. Bowman, and M.M. Goodman. 1987. Inheritance of resistance to gray leaf spot in maize. Crop Science 27:243-246.

Ullstrup, A.J. 1941. Inheritance of susceptibility to infection by Helminthosporium maydis race 1 in maize. Journal of Agricultural Research 63:331-334.

Ullstrup, A.J. 1944. Further studies on a species of parasitizing Helminthosporium corn. Phytopathology 34:214-222.

Ullstrup, A.J. 1965. Inheritance and linkage of a gene determining resistance in maize to an american race of Puccinia polysora. Phytopathology 55:425-428.

Ullstrup, A.J. 1972. The impact of the southern corn leaf blight epidemics of 1970-71. Annual Review of Pharmacology 10:37-50.

Vallad, G.E., and R.M. Goodman. 2004. Systemic acquired resistance and induced systemic resistance in conventional agriculture. Crop Science 44:1920-1934.

Wang, G.L., D.J. Mackill, J.M. Bonman, S.R. McCouch, M.C. Champoux, and R.J. Nelson. 1994. RFLP mapping of genes conferring complete and partial resistance to blast in a durably resistant rice cultivar. Genetics 136:1421-1434.

Ward, J.M.J., E.L. Stromberg, D.C. Nowell, and F.W. Nutter, Jr. 1999. Gray leaf spot: A disease of global importance in maize production. Plant Disease 83:884-895.

Welz, H.-G., and H.-H. Geiger. 2000. Genes for resistance to northern corn leaf blight in diverse maize populations. Plant Breeding 119:1-14.

Welz, H.G., A.W. Schechert, and H.H. Geiger. 1999a. Dynamic gene action at QTLs for resistance to Setosphaeria turcica in maize. Theoretical and Applied Genetics 98:1036-1045. 
Welz, H.G., X.C. Xia, P. Bassetti, A.E. Melchinger, and T. Lubberstedt. 1999b. QTLs for resistance to Setosphaeria turcica in an early maturing DentxFlint maize population. Theoretical and Applied Genetics 99:649-655.

White, D.G., ed. 1999. Compendium of corn diseases, 3rd ed. The American Phytopathological Society, St. Paul, Minnesota.

Williams, W.P., G.L. Windham, and P.M. Buckley. 2003. Enhancing maize germplasm with resistance to aflatoxin contamination. Toxin Reviews 22:175-193.

Wise, R.P., C.R. Bronson, P.S. Schnable, and H.T. Horner. 1999. The genetics, pathology, and molecular biology of T-cytoplasm male sterility in maize. Advances in Agronomy 65:79-130.

Wisser, R.J., Q. Sun, S.H. Hulbert, S. Kresovich, and R.J. Nelson. 2005. Identification and characterization of regions of the rice genome associated with broad-spectrum, quantitative disease resistance. Genetics 169:2277-2293.

Wisser, R.J., P.J. Balint-Kurti, and R.J. Nelson. 2006. The genetic architecture of disease resistance in maize: A synthesis of published studies. Phytopathology 96:120-129.

Wolters, P., T. Frey, A. Conceição, D. Multani, K. Broglie, S. Davis, K. Fengler, E. Johnson, K. Bacot, K. Simcox, T. Weldekidan, and J. Hawk. 2006. Map-based cloning of a QTL for anthracnose stalk rot resistance in Maize, Paper W412, Plant and Animal Genome Meeting, San Diego.

Xiao, S., S. Ellwood, O. Calis, E. Patrick, T. Li, M. Coleman, and J.G. Turner. 2001. Broad-spectrum mildew resistance in Arabidopsis thaliana mediated by RPW8. Science 291:118-120.

Xiao, W., J. Zhao, S. Fan, L. Li, J. Dai, and M. Xu. 2007. Mapping of genome-wide resistance gene analogs (RGAs) in maize (Zea mays L.). TAG Theoretical and Applied Genetics 115:501-508.

Yang, D.E., C.L. Zhang, D.S. Zhang, D.M. Jin, M.L. Weng, S.J. Chen, H. Nguyen, and B. Wang. 2004. Genetic analysis and molecular mapping of maize (Zea mays L.) stalk rot resistant gene Rfg1. TAG Theoretical and Applied Genetics 108:706-711.

Yun, S.J., L. Gyenis, P.M. Hayes, I. Matus, K.P. Smith, B.J. Steffenson, and G.J. Muehlbauer. 2005. Quantitative trait loci for multiple disease resistance in wild barley. Crop Science 45:2563-2572.

Zaitlin, D., S. Demars, and Y. Ma. 1993. Linkage of rhm, a recessive gene for resistance to southern corn leaf blight, to RFLP marker loci in maize (Zea mays) seedlings. Genome 36:555-564.

Zhang, L., A.S. Peek, D. Dunams, and B.S. Gaut. 2002. Population genetics of duplicated diseasedefense genes, hm1 and hm2, in maize (Zea mays ssp. mays L.) and its wild ancestor (Zea mays ssp. parviglumis). Genetics 162:851-860.

Zhou, N., T.-L. Tootle, and J. Glazebrook. 1999. Arabidopsis PAD3, a gene required for camalexin biosynthesis, encodes a putative cytochrome P450 monooxygenase. Plant Cell 11:2419-2428.

Zhu, S., K.-J. Leonard, and H.-F. Kaeppler. 2003. Quantitative trait loci associated with seedling resistance to isolates of Puccinia coronata in oat. Phytopathology 93:860-866. 